\title{
Students' Musical Preferences and Music Analysis Learning in Secondary Education
}

\author{
Roman Suarez Canedo \\ University of A Corunna
}

\begin{abstract}
This paper reports and ethnographic study which investigates the musical ideas, knowledge and contents present within a context of secondary education the subject of Music Analysis. This study shows how categories of music analysis used by students in their everyday life are different from that categories and methods studied within the subject, without stablishing a link between them. In this sense, it also demonstrates how the analysis methods taught in the classroom do not fit with most part of music styles preferred by students, showing a gap between youth culture and the music analyses is focused in this educational level.
\end{abstract}

\section{Introduction}

This ethnographic study seeks to illuminate the similarities and differences between the secondary students' conceptions and categories for the understanding of music and that transmitted within the music education process in the secondary school. The aim of this comparison is to avoid considering students as illiterate subjects in music.

\section{Investigation Approach}

Within the great body of research related to music education and the sociology of music, it is significant to point out that Thomas Regelski [1] has considered that the harnessing of music education to the students' everyday life is a great challenge for future music education research. This judgement is key, for Regelski, to convert music education into an "useful" subject for students, not only during their school years, but for all of their lives, no matter if they become music professionals or not. Following this author, music education should try to "make a difference". In this sense, Regelski defends a more paraxial musical instruction, directly related to questions of social specificity, and to variations in musical content and meanings. Furthermore, Robert Davis [2] has analyzed the relations among music, education and cultural identity, suggesting that music should be located as a movement within the field of cultural identity. Thus, Davis calls into question different "myths" omnipresent in music education such as the importance of the innate musical talent and so on.
David Elliott [3] upholds that feelings produced by music effects are not only related to sounds and musical designs, but to cultural, historical, stylistic and ideological dimensions as well. For all of this, Elliott suggests that it is necessary to value the incidence of feelings within the musical perception. Thus, this approach is linked to the matter of considering music social significance as a result of how music is apprehended within specific circumstances, rather than something pregiven and fixed in the music work itself [4]. This idea leads to considerate the issue of how music is experienced by real people, which is an important and active part of the process of meaning-making and music reception.

The understanding of how meaning and representation processes work both at linguistic and cultural levels is useful to analyze the formation of musical meaning. In this sense, Stuart Hall describes that "to belong to a culture is to belong to roughly the same conceptual and linguistic universe and to know how language can be interpreted to refer or reference the world" [5]. So to share all these things, is, indeed, to see the reality from within the same conceptual map and to make sense of it through the same language and cultural systems. As Hall points out, meaning is not something fixed and inherent to objects, but a result of cultural and linguistic conventions, and, hence, as he puts it, meanings can never be finally fixed. So to take part into a culture requires learning and internalizing the codes which allow us to express concepts and ideas through shared systems of representation, and to interpret ideas which are communicated to others using the same systems.

Taking these ideas within the domain of music education, we can observe that the categories of musical analysis taught to the students might not be shared by them, if these categories are not a part of a shared cultural code. It is necessary to observe the modes of musical analysis as a result of a concrete culture, musical language and practice: The music of the Western tradition and the musicology related to its study. As Tia DeNora [4] puts it the introduction of a reflexive conception of music force is needed. This concept should consider music as something constituted in relation to its reception without forgetting music internal properties. This brings us to consider how particular aspects of music come to be significant within particular recipients, in concrete contexts and moments. 
If we assume that musical meanings are not fixed, and are the result of social convention, it seems necessary to illuminate how students analyze and structure their musical knowledge and how these modes of "empirical analysis" are shared, enabling them to think and to communicate musical thoughts, and to classify music in categories that involve artistic, social, and emotional fields. In this sense, young people as social actors interpret and represent music in forms that contribute to shape its meaning. In this sense, for Lucy Green [6], it is clear that intrinsic musical meanings are not natural and essential to music works, and that they are a result of a determined ideology, based not only in rational judgements, but also in some myths taken for granted. Indeed, Green points out that musical meaning are artificial, historical and learnt. Therefore, listeners' responses to music are constraint by their competence and familiarity with a concrete music style. Complementing these arguments, Tia DeNora argues that most part of music exists in intertextual relation to compositional conventions and works, but also in relation to its past association with social situations, and from its social patterns of employment [4].

Furthermore, Paul Willis [7] considers popular music as a key site of common culture for symbolic work and creativity, especially for young people. For Willis, most young people have a clear understanding of musical different genres, and an ability to hear and place sounds in terms of their histories, influences and sources. Therefore, as this author puts it, people place music in their lives to use commodities and symbols for their own imaginative purposes and to generate their own particular aestethics. This would also engage with further research studying how ideology and social status influence musical tastes, and how social actors try to justify their tastes only with reference to aesthetic terms [8].

Within the sphere of musical analysis, some authors have detected a tendency to formalism in the mainstream methods (those applied and referred to classical music) in contrast with a priority on meaning issues in popular music analysis [9]. Much of this work has been semiotic or interpretative or has pursued theories of social and cultural homology. But within the context of music analysis as a secondary school subject, where both young musicians (studying in the conservatory) and students without specific instruction in music (those who pursuit to study performing arts and so on) study together, the construction of musical analysis from categories that students have already established and assumed as shared, seems to be a bridge needed to link their knowledge with the different academic approaches of music analysis. This is even more important given that these academic approaches are not part of the shared musical culture within the classroom.

Linking the above ideas with the curriculum of artistic subjects at school, we can considerate Jurjo Torres [10] judgements, when pointing out a global tendency to neglect curricular cultural selection which should enable students to understand a increasingly global world in constant change. And also the existence of hidden political and economical processes aiming a curricular uniformitarianism, where the cultural peculiarities of different social groups are sacrificed for a greater standarization of education oriented to labour formation as its main goal.

\section{Empirical study}

This study is an ethnographic research [11, 12], which intended to broaden the knowledge of the existing relations of both students and teachers with music within the context of a secondary classroom group. It sought to illuminate how the subject of music can, in secondary education, be "useful" to students in their musical life out of school. The adoption of this perspective is rooted in an important body of research which advocates music ethnography as a way of broadening our knowledge assuming music as a result of a social process of production, consumption and understanding [13, 4, 14].

For this research, we followed an emergent design, which required a constant reflective approach. For all of this, the data selection was a process of decision-making which, at the same time, enabled us to engage these data with the research design through a gradual selection [15]. Furthermore, the study became a circular flow, entailing an inductive understanding through the interplay of both data collecting and data analysis [12].

The selection of the research scenario was based in convenience criteria, selecting those cases which provided an easier access under the determined conditions [15]. The high school selected was the one where the researcher had studied during his secondary education years, and which is also placed in A Corunna, a city of Galicia, in the northwest of Spain. There is an introduction and description of all data collection techniques and instruments used in this research in Table 1.

Selection strategies within ethnographic model, are defined by their flexibility and adaptability and their integration throughout all the investigation stages. In this sense, during the field work period, one of the criteria that showed to be of more importance were the differences between those students who attended music studies in the Conservatory and those who did not attend music formation at that institution. The former had a greater importance within the classroom due to its previous 
knowledge in relation to harmony and musical analysis, which enabled them to help other students during the learning process. Another criteria, that arised through the different processes of investigation, was the necessity of a sincere and altruistic collaboration with the research. This criterion is based in the idea that musical preferences and opinions can only be transmitted within a atmosphere of confidence and understanding, which allowed the researcher to capture the plurality of the classroom-group under study.

During the investigation, the instruments and techniques or data collection were not defined before the field entrance, the role negotiation and the nonparticipant observation had begun. This was due to the importance of defining which data were relevant, and the development of the strategies of data collect which enabled the proper record of them.

In order to analyze the collected data, we followed a direct interpretation technique. In this sense, Stake asserts that researchers find meanings through directly interpreting individual examples, linking and adding them until it is possible to abstract common features from a group [16]. According with this, we tried to make sense of observations through an attentive analysis as well as a mostly descriptive data interpretation that entailed every analysis to be based in participants' testimonies, field notes or data from other sources.

In relation to credibility criteria, we used methodological triangulation with data collect processes, which implied the comparison of data from the same phenomenon obtained in different stages of the field work. We also compared testimonies of different participants within the field [17], as well as the agent triangulation [18]. Furthermore, the whole process was focused in trying to understand the perspectives of participants.

Table 1. Data collection techniques and instruments

\begin{tabular}{|l|l|l|}
\hline Techniques & Instruments & No. \\
\hline $\begin{array}{l}\text { Non- } \\
\text { participant } \\
\text { observation }\end{array}$ & Field diary & 8 \\
\hline Interviews: & $\begin{array}{l}\text { Interviews with the } \\
\text {-Individual- } \\
\text { Narrative }\end{array}$ & $\begin{array}{l}\text { Interview } \\
\text { students that attended } \\
\text { music instruction in } \\
\text { the conservatory }\end{array}$ \\
\cline { 2 - 4 } -Individual- \\
Ethnographic
\end{tabular}

\begin{tabular}{|l|l|l|}
\hline $\begin{array}{l}\text {-Group- } \\
\text { Ethnographic }\end{array}$ & $\begin{array}{l}\text { Interview with } \\
\text { students that did not } \\
\text { attend } \\
\text { conservatory }\end{array}$ & 1 \\
\hline Blog Analysis & $\begin{array}{l}\text { Register of blog } \\
\text { entries }\end{array}$ & $\begin{array}{l}163 \\
\text { entries }\end{array}$ \\
\hline $\begin{array}{l}\text { Analysis of } \\
\text { Classroom } \\
\text { Materials }\end{array}$ & Scores used in lessons & 8 \\
\hline $\begin{array}{l}\text { Analysis of } \\
\text { Classroom } \\
\text { Bibliography }\end{array}$ & $\begin{array}{l}\text { Bibliography in which } \\
\text { the lessons were based }\end{array}$ & 3 books \\
\hline
\end{tabular}

On the other hand, we take into account the role of the researcher that tried to understand the different perspectives expressed by participants, while declaring his academic formation within the classical music, as a pianist, and his knowledge of popular music as a professional musician in popular and urban music participating mainly in the local and regional music scene. We consider the researcher previous background when analyzing his positioning and elections, both those intentional and those non intentional, within his disciplined subjectivity [11].

The fiability of the research procedure is based on declaring the origin of all data, their record circumstances and the existing frontier between data and the researcher reconstruction. In order to warrant these questions, interpretations from data analysis had a prevalent more descriptive approach than interpretative, and for that the ethnographic report is based in participants' testimonies and evidences from informants or original documents collected in the field.

The structure of the ethnographic report is divided in two different parts. The first is referred to the music styles and student musical preferences, where we reconstruct different music styles through the testimonies of participants. These testimonies are not only referred to pure musical judgements but also to social beliefs and feelings. The second part is referred to the subject of Music Analysis, and the ideas that expressed both students and the teacher, and also analyzing the curriculum and documents recorded in the learning process within the classroom.

\section{Research Findings}

Musical identities play an important role for young people to shape their personality and differentiate themselves from peers. These identities are defined by its fragmentary nature, so students participate of diverse identity positions simultaneously or changing over time. Furthermore, musical identities are built from a selection of subjective experiences and ideas which make sense 
through the narration. In this sense, "coherence" would be the narrativation.

While studying the musical preferences of students, the degree of musical instruction appeared to be the most important item to explain how students approached different music styles. Indeed, students who had a higher musical instruction showed more respect for different music styles than those students with lower instruction. Related to this, students who attended studies at the Conservatory had less defined musical identities. This findings show how individuals have a great dependence on the cultural environment in which they live, which is the base of the connections that people are able to make among past, present and future.

Students recognized different influences when configuring their musical taste. The main influence was their social environment, specially their family (parents) and their friends. While their peers appeared to be more important when talking about modern music, parents' influence was often related to their younghood musical tastes.

Students also recognized that mass media were of great influence. They considered the internet to be the strongest factor when configuring their musical taste. This impact was greater for "commercial music" or those musics considered to be "radio formula". Related to this, there was a global tendency to prefer music with English lyrics (mainly from US and UK bands), that had substituted other local, regional or national options.

Emotional, ideological and other "extra-musical" judgements are key in the students' analysis of popular music, meanwhile they are not taken into account by the curriculum of Music Analysis, focused mainly in structural properties that are "inherent" to music. We have observed different levels of prestige depending on the music style, as it was described by Bourdieu. Related to this, those music styles with less academic prestige were attached to different social activities and habits that justified them (having fun with peers, dancing...). On the contrary, those music styles that were considered prestigious were not attached to any functionality to justify their consumption.

Student analysis of popular music within their schoolwork is has been limited to translate categories of analysis from classical music to popular music. Furthermore, these categories of analysis do not always fit the specifities of popular music styles. In this sense, the student contribution to analysis with previous or non-scholar musical knowledge is constrained by analysis methods that are central in the lessons. As a result, there is a lost opportunity to harness new musical knowledge learnt at school with the students' previous music culture

The Music Analysis subject is mainly based in learning to analyze classical music. In this sense, some ideological conceptions are unconsciously translated to students, such as most part of popular music styles "come" from classical music tradition (and that it is the base of popular music), establishing hierarchical categories of music styles based in extramusical believes.

The music teacher has developed an important labour trying to make music analysis closer to students' interests. In this way, she had proposed her students an activity where everyone should to analyze their favourite songs, explaining their musical preferences. This activity showed them how to develop analytical skills, learnt at school, in their daily life. Indeed, this activity helped to save the difference of status among any kind of music within the classroom.

\section{Conclusion}

Most secondary school students have a clear understanding of music, developed, at least partially, out of school while music education misses the opportunity to engage the students' knowledge in the music learning process. This situation leds the music teacher in a situation where he or she has to individually decide whether to use music closer to students or not during the learning process. In this sense, within the pedagogy of music analysis, further research is needed to seek new approaches for taking into account the existing categories and hierarchies that allow students to "make sense" of music.

We consider important to continue this line of research studying more specifically the musical background and social uses that both students and teacher give to music outside the classroom. It would enable to determine how they influence the configuration of the learning process.

\section{References}

[1] Regelski, T. (2009). La musica y la educacion musical: Teoria y practica para "marcar una diferencia". In David $\mathrm{K}$. Lines (editor), La educacion musical para el nuevo milenio. Madrid: Ediciones Morata.

[2] Davis, R. (2009). Educación musical e identidad cultural. In David K. Lines (editor), La educación musical para el nuevo milenio. Madrid: Ediciones Morata.

[3] Elliott, D. J. (2009). La comprension musical, las obras musicales y la expresion de los sentimientos: Implicaciones para la educacion. In David K. Lines (editor). La educacion musical para el nuevo milenio. Madrid: Ediciones Morata.

[4] DeNora, T. (2000). Music in everyday life. Cambridge: Cambridge University Press.

[5] Hall, S. (ed) (1997). Representation: Cultural representations and signifying practices. London: Sage Publications- The Open University., pp. 22-24 
[6] Green, L. (2001). Música, genero y educacion. Madrid: Ediciones Morata.

[7] Willis, P. (1990). Common Culture. Buckingham: Open University Press.

[8] Bourdieu, P. (1988). La distincion. Criterios y bases sociales del gusto. Madrid. Taurus.

[9] Middleton, R. (1993). Popular music and musicology: Bridging the gap. Popular Music, vol.12 (May), p. 177190.

[10] Torres Santome, J. (2010). La justicia curricular. El caballo de Troya de la cultura escolar. Madrid. Ediciones Morata.

[11] Goetz, J. P. and LeCompte, M. D. (1988). Etnografia y diseño cualitativo en investigación educativa. Madrid: Ediciones Morata.

[12] Simons, H. (2011). El estudio de caso: Teoría y práctica. Madrid: Ediciones Morata.

[13] Willis, P. (2000). Ethnographic imagination. Cambridge: Polity Press.

[14] Martin, P. J. (2007). Music and the sociological gaze. Manchester: Manchester University Press.

[15] Flick, U. (2002). Introduccion a la investigación cualitativa. Madrid-Galiza: Ediciones Morata and Fundación Paideia Galiza.

[16] Stake, R. E.(1998). Investigacion con estudios de caso. Madrid: Ediciones Morata.

[17] Hammersley, M. and Atkinson, P. (1994). Etnografia. Barcelona: Ediciones Paidós Iberica. 